\title{
The production of renal calcinosis by magnesium deficiency in rainbow trout (Salmo gairdneri)
}

\author{
BY C. B. COWEY, D. KNOX, J. W. ADRON, S. GEORGE \\ AND B. PIRIE \\ Institute of Marine Biochemistry, St Fittick's Road, \\ Aberdeen $A B 13 R A$
}

(Received 8 September 1976 - Accepted 1 November 1976)

\begin{abstract}
1. Replicate groups of rainbow trout (Salmo gairdneri) were given one of five experimental diets (diets 1-5) for 16 weeks. The diets contained different amounts of calcium, phosphorus and magnesium and were prepared so that there were three levels of $\mathrm{Ca}(\mathrm{g} / \mathrm{kg}): 14$ (diet 1), 26 (diets 2 and 3) and 40 (diets 4 and 5 ), $\mathrm{Ca}: \mathrm{P}$ being approximately $1: 1$ in all diets. Diets 1,2 and 4 had basal $\mathrm{Mg}$ levels (not more than $0.063 \mathrm{~g} / \mathrm{kg}$ ) whereas diets 3 and 5 contained supplementary $\mathrm{Mg}(1.0 \mathrm{~g} / \mathrm{kg})$.

2. Weight gains of the trout given diets containing supplementary $\mathrm{Mg}$ were twice those of trout given diets with basal levels of $\mathrm{Mg}$. At both dietary $\mathrm{Mg}$ concentrations weight gain was unaffected by the dietary $\mathrm{Ca}$ level.

3. Serum $\mathrm{Mg}$ levels were significantly reduced in those trout given diets without supplementary $\mathrm{Mg}$. The serum $\mathrm{Ca}$ level in those trout given the lowest concentration of $\mathrm{Ca}$ in their diet $(14 \mathrm{~g} / \mathrm{kg}$, diet 1) was significantly greater than in those given higher amounts of $\mathrm{Ca}$ in their diets. Serum $\mathrm{P}$ levels were not significantly different with any of the experimental diets.

4. The renal $\mathrm{Ca}$ concentration was increased in trout given diet $3(26 \mathrm{~g} \mathrm{Ca} / \mathrm{kg}$; basal Mg Jevels). No further increase in renal Ca concentration occurred in trout given diet $5(40 \mathrm{~g} \mathrm{Ca} / \mathrm{kg}$; basal $\mathrm{Mg}$ levels). With diets containing supplementary $\mathrm{Mg}$ renal $\mathrm{Ca}$ levels were increased at a dietary $\mathrm{Ca}$ level of $40 \mathrm{~g} / \mathrm{kg}$ but not at a dietary Ca level of $26 \mathrm{~g} / \mathrm{kg}$. Renal $\mathrm{Mg}$ and $\mathrm{P}$ concentrations were not significantly different between any of the dietary treatments.

5. Renal calculi were demonstrated by light and electron microscopy in tubules of those trout given diets 3 and 5 (basal $\mathrm{Mg} ; 26$ and $40 \mathrm{~g} \mathrm{Ca} / \mathrm{kg}$ respectively). Electron-probe micro-analysis showed that these calculi contained or comprised tricalcium phosphate.

6. The skeletal muscle of $\mathrm{Mg}$-deficient trout contained significantly more sodium than that of normal trout. It is suggested that this is indicative of an increase in extracellular fluid in the muscle of $\mathrm{Mg}$-deficient trout.
\end{abstract}

A fundamental relationship exists between magnesium, calcium and phosphorus in the nutrition of birds and mammals (Forbes, 1963). This interdependence has been intensively studied and abnormalities arising from a reduction in the ratios, $\mathrm{Mg}: \mathrm{Ca}$ and $\mathrm{Mg}: \mathrm{P}$ are now well characterized. One of the most striking symptoms of $\mathrm{Mg}$ deficiency in birds and mammals is calcification of the kidney and other soft tissues (Britton \& Stokstad, 1970; O’Dell, Morris \& Regan, 1960).

$\mathrm{Mg}$ deficiency in carp (Cyprinus carpio) has been characterized by high mortality, poor growth, loss of appetite, sluggishness and convulsions, but soft tissues were not examined for any derangement of $\mathrm{Mg}$, Ca or P metabolism (Ogino \& Chiou, 1976). Although the kidney of freshwater fish acts primarily to conserve electrolytes and the urine concentrations of $\mathrm{Mg}$ and $\mathrm{Ca}$ are normally low (Hickman \& Trump, 1969) nevertheless calculi have been observed in the kidneys of rainbow trout (Salmo gairdneri) under certain conditions not apparently associated with mineral imbalance (Smith, Brin \& Halver, 1974; Kloppel \& Post, 1975).

Many fish foodstuffs contain relatively large amounts of components (such as fish meal) that have comparatively high contents of $\mathrm{Ca}$ so that abnormalities arising from a high $\mathrm{Ca}$ intake or an imbalance of $\mathrm{Ca}, \mathrm{Mg}$ and $\mathrm{P}$ are of practical interest. Finally, there is evidence that $\mathrm{Mg}$ deficiency symptoms in mammals are exacerbated by a high protein intake (Bunce, Reeves, Oba \& Sauberlich, 1963) and by lowering the environmental temperature (Hegsted, 
Vitale \& McGrath, 1956). As both these factors feature in the life of fish these animals might appear especially prone to abnormalities resulting from $\mathrm{Mg}$ deficiency.

We have therefore studied the effect of $\mathrm{Mg}$ deficiency on the growth and kidney pathology of rainbow trout given diets containing up to $40 \mathrm{~g} / \mathrm{kg} \mathrm{Ca}$ and $\mathrm{P}$.

\section{EXPERIMENTAL}

\section{Animals}

Rainbow trout of approximate mean weight $30 \mathrm{~g}$ were obtained from D. M. Brien, Almondbank, Perth; they had been reared on a commercial diet (Beta trout diet, Cooper Nutrition Products Ltd, Stepfield, Witham, Essex) containing (g/kg) 400 crude protein (nitrogen $\times$ 6.25), 45 oil and 45 fibre (manufacturers' specification). On analysis this diet contained $(\mathrm{g} / \mathrm{kg}) 3.27 \mathrm{Mg}, 50.35 \mathrm{Ca}$ and $52.8 \mathrm{P}$. The trout were randomly distributed among fifteen fibreglass tanks $(0.7 \times 0.8 \times 0.6 \mathrm{~m}$ deep) twenty fish/tank, three tanks/treatment and given, manually, a diet similar to diet 1 (Table 1) except that it contained $0.5 \mathrm{~g} \mathrm{Mg} / \mathrm{kg}$. Within $3 \mathrm{~d}$ this diet was readily accepted by the fish.

Water from the City of Aberdeen domestic supply flowed into an elevated reservoir tank where it was heated to $15 \pm 1^{\circ}$ and vigorously aerated. Water from this reservoir was distributed to the fish tanks at the rate of $1.01 / \mathrm{min}$ per $\mathrm{kg}$ biomass fish; this water contained less than $0.7 \mu \mathrm{mol}$ chlorine $/ 1$, it was not recirculated and ran to waste after leaving the fish tanks. Fish were fed to satiation four times/d (between 08.30 and 16.30 hours), food pellets being put sparingly into each tank only so long as they were actively consumed. Fish were fed $6 \mathrm{~d} /$ week, one person only doing the feeding. The tanks were housed in an aquarium room with an ambient temperature averaging $15^{\circ}$.

When the fish were completely accustomed to the experimental diet (about $10 \mathrm{~d}$ ) initial weight measurements were made. All fish from each tank in turn were removed by hand-net into a 101 bucket of water. Water was then poured from this bucket through a net which retained the fish. The net was allowed to drain for $10 \mathrm{~s}$ and the fish carefully transferred without handling to a second bucket of water which was already in position and tared on a top pan balance (Mettler P10, Gallenkamp \& Co Ltd, East Kilbride, Scotland). After weighing, the fish were immediately returned to the fish tank and when all groups had been weighed replicate tanks were given the five experimental diets (see Table 1). Thereafter fish were weighed every 4 weeks throughout the experiment which lasted 16 weeks.

\section{Diets}

The composition of the experimental diets used is shown in Table 1; they were prepared in bulk as described previously (Cowey, Adron, Brown \& Shanks, 1975) and made into moist pellets using an Alexanderwerk pelleting machine (Orthos (Engineering) Ltd, Market Harborough, Leicestershire). The pellets were freeze-dried then stored at $-20^{\circ}$ until required.

The actual quantities of $\mathrm{Ca}, \mathrm{P}$ and $\mathrm{Mg}$ in the diets by analysis, are shown in Table 1 . The intention was to compare the effects on growth and kidney histology of diets containing $\mathbf{M g}$ at either a basal level or a level of $1.0 \mathrm{~g} / \mathrm{kg}$, together with Ca levels of 15,25 and $40 \mathrm{~g} / \mathrm{kg}$, dietary $\mathrm{Ca}: \mathrm{P}$ being $1: 1$. With the aquarium resources available, however, it was not possible to include a diet containing supplementary $\mathrm{Mg}$ at the lowest $\mathrm{Ca}$ and $\mathrm{P}$ level used. It can be seen from Table 1, that excluding the $P$ level of diet 1 , there was good agreement between the intended levels of $\mathrm{Ca}, \mathrm{P}$ and $\mathrm{Mg}$ in the diets and the amounts found by analysis. 
Table 1. Composition ( $\mathrm{g} / \mathrm{kg}$ dry diet) of the experimental diets given to rainbow trout (Salmo gairdneri)

\begin{tabular}{|c|c|c|c|c|c|}
\hline \multirow[b]{2}{*}{ Ingredient } & \multicolumn{5}{|c|}{ Diet } \\
\hline & 1 & 2 & 3 & 4 & 5 \\
\hline Casein* & 500 & 500 & 500 & 500 & 500 \\
\hline Dextrin & 100 & 100 & 100 & 100 & 100 \\
\hline Cod-liver oil & 20 & 20 & 20 & 20 & 20 \\
\hline Soya-bean oil & 40 & 40 & 40 & 40 & 40 \\
\hline Mineral mixture $\dagger$ & $34 \cdot 7$ & 34.7 & $34 \cdot 7$ & $34 \cdot 7$ & $34 \cdot 7$ \\
\hline Vitamin mixture $\ddagger$ & 28 & 28 & 28 & 28 & 28 \\
\hline$\alpha$-Cellulose & $201 \cdot 3$ & $133 \cdot 2$ & $123 \cdot 1$ & $65 \cdot 2$ & $55 \cdot 1$ \\
\hline Binder\$ & 50 & 50 & 50 & 50 & 50 \\
\hline Calcium lactate & 26 & 26 & 26 & 26 & 26 \\
\hline $\mathrm{CaHPO}_{4} 2 \mathrm{H}_{2} \mathrm{O}$ & 0 & $50 \cdot 9$ & 50.9 & $101 \cdot 8$ & $101 \cdot 8$ \\
\hline $\mathrm{NaH}_{2} \mathrm{PO}_{4}$ & 0 & $17 \cdot 2$ & $17 \cdot 2$ & $34 \cdot 3$ & $34 \cdot 3$ \\
\hline $\mathrm{MgSO}_{4} \cdot 7 \mathrm{H}_{2} \mathrm{O}$ & 0 & 0 & $10 \cdot 1$ & 0 & $10 \cdot 1$ \\
\hline \multicolumn{6}{|l|}{ Chemical composition } \\
\hline Calcium & $14 \cdot 16$ & $26 \cdot 47$ & $27 \cdot 36$ & 39.79 & $39 \cdot 85$ \\
\hline Phosphorus & $11 \cdot 55$ & $24 \cdot 83$ & 25.07 & 39.04 & $39 \cdot 35$ \\
\hline Magnesium & 0.026 & 0.040 & 0.997 & 0.063 & 1.005 \\
\hline
\end{tabular}

* Supplemented with $(\mathrm{g} / 950 \mathrm{~g}$ casein): arginine 25 , cystine 10 , methionine 10 , and tryptophan 5.

† Supplied (/kg dry diet): $\mathrm{Ca}\left(\mathrm{H}_{2} \mathrm{PO}_{4}\right)_{2} \cdot \mathrm{H}_{2} \mathrm{O} 24.3 \mathrm{~g}, \mathrm{CaCO}_{3} 5 \cdot 2 \mathrm{~g}, \mathrm{FeSO}_{4} .7 \mathrm{H}_{2} \mathrm{O} 1 \cdot 0 \mathrm{~g}, \mathrm{KCl} 2 \cdot 1 \mathrm{~g}, \mathrm{NaCl}$ $1.7 \mathrm{~g}, \mathrm{Al}_{2}\left(\mathrm{SO}_{4}\right)_{3} .16 \mathrm{H}_{2} \mathrm{O} 6.9 \mathrm{mg}, \mathrm{ZnSO}_{4} .7 \mathrm{H}_{2} \mathrm{O} 139 \mathrm{mg}, \mathrm{CuSO}_{4} .5 \mathrm{H}_{2} \mathrm{O} 34.7 \mathrm{mg}, \mathrm{MnSO}_{4} .4 \mathrm{H}_{2} \mathrm{O} 124.9 \mathrm{mg}, \mathrm{KI}$ $6.9 \mathrm{mg}, \mathrm{CoSO}_{4} .7 \mathrm{H}_{2} \mathrm{O} 34.7 \mathrm{mg}$.

* Supplied $(/ \mathrm{kg}$ dry diet): riboflavin $200 \mathrm{mg}$, pyridoxine hydrochloride $40 \mathrm{mg}$, nicotinic acid $800 \mathrm{mg}$, calcium pantothenate $280 \mathrm{mg}$, myo-inositol $4 \mathrm{~g}$, biotin $6 \mathrm{mg}$, pteroylmonoglutamic acid $15 \mathrm{mg}, p$-aminobenzoic acid $400 \mathrm{mg}$, choline chloride $8 \mathrm{~g}$, ascorbic acid $2 \mathrm{~g}$, DL- $\alpha$-tocopheryl acetate $400 \mathrm{mg}$, menaphthone $40 \mathrm{mg}$, cyanocobalamin $90 \mu \mathrm{g}$, thiamin hydrochloride $50 \mathrm{mg}$.

$\S$ Methofas; ICI Ltd, Ardrossan, Ayrshire.

\section{Chemical methods}

Replicate samples of each diet were ashed in a muffle furnace at $600^{\circ}$ for $18 \mathrm{~h}$. The ash was dissolved in a solution of strontium chloride hexahydrate $\left(30.4 \mathrm{~g} \mathrm{SrCl}_{2} 6 \mathrm{H}_{2} \mathrm{O} / 1\right.$, the $\mathrm{Sr}$ solution) containing also $1 \mathrm{M}$-hydrochloric acid; it was then made to volume $(10 \mathrm{ml})$ with $\mathrm{Sr}$ solution. Portions of the sample suitably diluted with $\mathrm{Sr}$ solution were analysed for $\mathrm{Ca}$ and $\mathrm{Mg}$ by atomic absorption spectroscopy. Reagent blanks and standard solutions of $\mathrm{Ca}$ and $\mathrm{Mg}$ in $\mathrm{Sr}$ solution and containing $\mathrm{HCl}$ at the same concentration as the test samples, were also analysed, with the $\mathrm{Sr}$ preventing phosphate interference in the $\mathrm{Ca}$ and $\mathrm{Mg}$ estimations. Separate portions of the ashed sample were appropriately diluted with deionized, distilled water for P analysis (Bartlett, 1958).

Kidneys were analysed by the same procedure. Serum from blood obtained from the caudal vein of trout was deproteinized with trichloroacetic acid $(50 \mathrm{~g} / 1$ final concentration) before dilution with $\mathrm{Sr}$ solution. Serum $\mathrm{Ca}$ and $\mathrm{Mg}$ levels were then estimated by atomic absorption spectroscopy, aspirating the diluted serum directly into the flame of the spectrometer. Inorganic P was measured in separate portions of serum by the method of Bartlett (1958) after deproteinization with trichloroacetic acid.

Portions of skeletal muscle were treated in the same manner as were the kidneys before $\mathrm{Ca}$ estimation. Sodium and potassium levels in the solutions of ashed muscle were also estimated by flame emission spectroscopy.

Analyses were carried out on tissues from ten fish/treatment. Trout were killed by means of a sharp blow on the head, a blood sample taken from the caudal vein and tissues immediately removed. These were either weighed and ashed immediately, or stored in separate, 
Table 2. Total initial and final weights and food consumption of groups of rainbow trout (Salmo gairdneri) given diets containing different amounts of calcium and magnesium

(Mean values with their standard errors for three tanks each with twenty fish)

\begin{tabular}{|c|c|c|c|c|c|c|c|}
\hline \multirow[b]{3}{*}{ Diet no.* } & \multicolumn{4}{|c|}{$\begin{array}{l}\text { Total biomass } \\
(\mathrm{g} / \text { tank })\end{array}$} & \multirow{2}{*}{\multicolumn{2}{|c|}{$\begin{array}{c}\text { Food } \\
\text { consumption } \\
(\mathrm{g} / \operatorname{tank})\end{array}$}} & \multirow{3}{*}{$\begin{array}{l}\text { g weight } \\
\text { gain } / \mathbf{g} \\
\text { food eaten }\end{array}$} \\
\hline & \multicolumn{2}{|c|}{ Initial } & \multicolumn{2}{|c|}{ Final } & & & \\
\hline & Mean & $\mathbf{S E}$ & Mean & SE & Mean & SE & \\
\hline $\begin{array}{l}1 \\
2 \\
3 \\
4 \\
5\end{array}$ & $\begin{array}{l}645 \\
658 \\
626 \\
636 \\
635\end{array}$ & $\begin{array}{r}10 \\
12 \\
9 \\
10 \\
9\end{array}$ & $\begin{array}{l}1276 \\
1320 \\
1980 \dagger \\
1254 \\
2068 \dagger\end{array}$ & $\begin{array}{l}20 \\
23 \\
29 \\
25 \\
30\end{array}$ & $\begin{array}{l}990 \\
1020 \\
1290 \dagger \\
1030 \\
1510 \dagger\end{array}$ & $\begin{array}{r}30 \\
45 \\
80 \\
50 \\
105\end{array}$ & $\begin{array}{l}0.64 \\
0.65 \\
1.05 \\
0.60 \\
0.95\end{array}$ \\
\hline
\end{tabular}

sealed polythene bags at $-20^{\circ}$ until they could be analysed, or placed in fixative for histological analysis.

\section{Histological methods}

For light microscopy, small pieces of kidney from six fish/treatment were fixed in a solution containing $40 \mathrm{~g}$ formaldehyde/l and $0.05 \mathrm{M}$-phosphate, $\mathrm{pH} 7 \cdot 0$. Paraffin wax sections (thickness $4 \mu \mathrm{m}$ ) were cut and stained by the silver method of Von Kóssa (Pearse, 1972) which depends on the presence of phosphate or carbonate (although insoluble phosphates and carbonates in animal tissues are nearly always those of $\mathrm{Ca}$ ) and by the phthalocyanin method for $\mathrm{Ca}$ (Pearse, 1972). Other paraffin sections were stained with haematoxylin and eosin.

For electron microscopy, samples of kidney tissues from three trout from each experimental group were fixed at $4^{\circ}$ for $60 \mathrm{~min}$ in a solution containing $40 \mathrm{~g}$ formaldehyde $/ 1,50 \mathrm{~g}$ glutaraldehyde $/ 1$ and $0.1 \mathrm{M}$-sodium cacodylate, $\mathrm{pH} 7 \cdot 6$. The samples were then briefly post-fixed in cacodylate-buffered osmium tetroxide $(20 \mathrm{~g} / 1), \mathrm{pH} 7 \cdot 6$, dehydrated in graded alcohols and propylene oxide, then embedded in araldite. Ultra-thin sections were examined in an electron microscope (Philips EM 201:Pye Unicam Ltd, Cambridge) operating at $40 \mathrm{kV}$. Electron probe $\mathrm{x}$-ray microanalysis was carried out with an analytical electron microscope (AEI CORA; AEI Scientific Instruments Ltd, Manchester) or a scanning electron microscope (Philips PSEM 500) fitted with transmission and X-ray detectors.

\section{RESULTS}

There was no mortality among the fish given the experimental diets; apart from a sluggishness apparent in the trout given diet 4 , there were no behavioural or gross external abnormalities.

The weight gains of the trout are shown in Table 2. Fish given diets 3 and 5 gained significantly more weight than those given the other three diets. The weight gains of those fish given diets containing only basal levels of $\mathrm{Mg}$ (diets 1,2 and 4) were not themselves significantly different, and during the experimental period high dietary $\mathrm{Ca}$ and $\mathrm{P}$ levels $(40 \mathrm{~g} / \mathrm{kg}$; diet 4) were not themselves more deleterious in respect of weight gain than lower dietary $\mathrm{Ca}$ levels (14 $\mathrm{g} / \mathrm{kg}$; diet 1$)$ under conditions of $\mathrm{Mg}$ deficiency.

Food consumption is also shown in Table 2 . Trout given diets containing supplementary 
Table 3. Mean concentrations ( $\mu$ molll) of calcium, phosphate and magnesium in the sera of rainbow trout (Salmo gairdneri) given diets containing different amounts of these minerals

(Mean values with their standard errors for ten fish/treatment)

\begin{tabular}{|c|c|c|c|c|c|c|}
\hline \multirow[b]{2}{*}{ Diet no.* } & \multicolumn{2}{|c|}{$\mathrm{Ca}$} & \multicolumn{2}{|c|}{ Phosphate } & \multicolumn{2}{|c|}{$\mathbf{M g}$} \\
\hline & Mean & SE & Mean & $\mathrm{SE}$ & Mean & $\mathrm{SE}$ \\
\hline 1 & $5200+$ & 163 & $6 \cdot 1$ & 0.3 & 234 & $12 \cdot 1$ \\
\hline 2 & 4630 & 110 & 6.5 & 0.3 & 323 & 57.5 \\
\hline 3 & 4280 & 78 & $6 \cdot 1$ & 0.2 & $905 \dagger$ & $75 \cdot 8$ \\
\hline 4 & 4380 & 80 & $5 \cdot 8$ & 0.3 & 355 & $26 \cdot 7$ \\
\hline 5 & 4380 & 110 & 6.5 & 0.3 & $915 \dagger$ & $41 \cdot 7$ \\
\hline
\end{tabular}

$\mathrm{Mg}$ consumed significantly more food than trout given diets deficient in $\mathrm{Mg}$. Thus $\mathrm{Mg}$ deficiency led to loss of appetite. In addition the ratio, weight gain: food eaten was markedly inferior in $\mathrm{Mg}$-deficient trout to that in normal trout, food conversion being adversely affected by $\mathrm{Mg}$-deficiency.

$\mathrm{Mg}$ and $\mathrm{Ca}$ were monitored in the aquarium water during the experiment, the mean concentrations $(\mathrm{mmol} / \mathrm{l})$ found were $0.05 \mathrm{Mg}$ and $0.17 \mathrm{Ca}$. Although freshwater fish do have the capacity to take up some ions from the water through the gills or other permeable surfaces (Ichikawa \& Oguri, 1961; Templeton \& Brown, 1963) any such capability with respect to $\mathrm{Mg}$ was clearly inadequate to compensate for $\mathrm{Mg}$ deficiency in the diet under the prevailing conditions.

Serum $\mathrm{Mg}$ concentrations were 3-4-fold lower in trout given the diets deficient in $\mathbf{M g}$ than in those given diets containing supplementary $\mathrm{Mg}$ (Table 3). Serum $\mathrm{Ca}$ concentration was slightly, but significantly, increased in those trout given diet 1 containing the lowest levels of $\mathrm{Ca}(14 \mathrm{~g} / \mathrm{kg})$ and $\mathrm{Mg}(26 \mathrm{mg} / \mathrm{kg})$ employed in the experimental treatments. These trout apart, serum $\mathrm{Ca}$ and orthophosphate concentrations were similar in trout given the five experimental diets, so that even up to high levels of $\mathrm{Ca}$ and $\mathrm{P}$ intake serum levels of these minerals were controlled and this control was not affected by a low dietary $\mathrm{Mg}$ level.

The $\mathrm{Mg}$ content of the kidneys of trout was constant irrespective of $\mathrm{Mg}$ level in the experimental diet (Table 4). However, the $\mathrm{Ca}$ content of the kidney was greatly influenced by dietary $\mathrm{Mg}$ level; at a dietary $\mathrm{Ca}$ concentration of approximately $25 \mathrm{~g} / \mathrm{kg}$ the $\mathrm{Ca}$ content of the kidney was 7-fold greater in trout given a diet deficient in $\mathrm{Mg}$ compared with those given supplementary $\mathrm{Mg}$ (diet $2 v$. diet 3; Table 4). In the absence of supplementary $\mathrm{Mg}$, increasing the dietary $\mathrm{Ca}$ concentration to $40 \mathrm{~g} / \mathrm{kg}$ did not significantly increase the renal Ca levels (diet $2 v$. diet 4), but at this dietary $\mathrm{Ca}$ concentration, renal $\mathrm{Ca}$ levels were increased even in the presence of supplementary $\mathrm{Mg}$ (diet $4 v$. diet 5). At the lowest dietary $\mathrm{Ca}$ level $(14 \mathrm{~g} / \mathrm{kg}$; diet 1$)$ the renal Ca concentration was $0.86 \mathrm{~g} / \mathrm{kg}$. Had facilities permitted the use of a comparable diet containing supplementary $\mathrm{Mg}$ it is likely that the kidney $\mathrm{Ca}$ levels resulting would have been significantly lower, because the kidneys of hatchery-reared trout (for details of mineral levels see p. 128) contained (mean $\pm \mathrm{SE} ; \mathrm{g} / \mathrm{kg}$ ) $0.15 \pm 0.004 \mathrm{Mg}$, $0.17 \pm 0.02 \mathrm{Ca}$ and $2.23 \pm 0.05 \mathrm{P}$.

Histological examination of the trout kidneys revealed the presence of $\mathrm{Ca}$ deposits in the proximal tubules of all fish given diet 4 . The $\mathrm{Ca}$ deposits completely blocked the lumen of the tubules, the epithelial cells of which were necrotic (Plate $1 \mathrm{~A}$ and B). Renal calculi were also present in the trout given diet 2 , but were not seen in sections from every individual examined; 
Table 4. Mean concentrations ( $\mathrm{g} / \mathrm{kg}$ wet weight) of calcium, phosphorus, magnesium and ash in the kidneys of rainbow trout (Salmo gairdneri) given diets containing different amounts of these minerals

(Mean values with their standard errors for ten fish/treatment)

\begin{tabular}{|c|c|c|c|c|c|c|c|c|}
\hline \multirow[b]{2}{*}{ Diet no.* } & \multicolumn{2}{|c|}{$\mathrm{Ca}$} & \multicolumn{2}{|c|}{$\mathbf{P}$} & \multicolumn{2}{|c|}{$\mathrm{Mg}$} & \multicolumn{2}{|c|}{ Ash } \\
\hline & Mean & SE & Mean & $\mathbf{S E}$ & Mean & $\mathrm{SE}$ & Mean & SE \\
\hline $\begin{array}{l}1 \\
2 \\
3 \\
4 \\
5\end{array}$ & $\begin{array}{l}0 \cdot 86^{\mathrm{a}} \\
2 \cdot 88^{\mathrm{b}} \\
0 \cdot 40^{\mathrm{a}} \\
2 \cdot 83^{\mathrm{b}} \\
1 \cdot 59^{\mathrm{b}}\end{array}$ & $\begin{array}{l}0.26 \\
0.96 \\
0.07 \\
0.82 \\
0.68\end{array}$ & $\begin{array}{l}3 \cdot 00^{\mathrm{a}} \\
4 \cdot 16^{\mathrm{a}} \\
3 \cdot 05^{\mathrm{a}} \\
4 \cdot 10^{\mathrm{a}} \\
3 \cdot 08^{\mathrm{a}}\end{array}$ & $\begin{array}{l}0.14 \\
0.42 \\
0.18 \\
0.45 \\
0.28\end{array}$ & $\begin{array}{l}0.15^{a} \\
0.15^{a} \\
0.15^{a} \\
0.15^{a} \\
0.15^{a}\end{array}$ & $\begin{array}{l}0.002 \\
0.003 \\
0.003 \\
0.002 \\
0.006\end{array}$ & $\begin{array}{l}14 \cdot 81^{\mathrm{a}} \\
19 \cdot 83^{\mathrm{a}} \\
14 \cdot 16^{\mathrm{a}} \\
20 \cdot 14^{\mathrm{a}} \\
15 \cdot 25^{\mathrm{a}}\end{array}$ & $\begin{array}{l}0.57 \\
2.74 \\
0.32 \\
2.11 \\
1.52\end{array}$ \\
\hline
\end{tabular}

Values in the same column with unlike superscripts were significantly different $(P<0.01)$.

* For details, see Table 1.

qualitatively their incidence was lower than in fish given diet 4 . No renal calculi were present in any of the sections from individuals given diets $\mathrm{I}, 3$ and 5.

Electron microscopy of the kidneys of the experimental trout indicated that two types of deposit were present in the kidneys of abnormal individuals, these we have denoted types 1 and 2. The 'type 1' deposits (Plate 2A) were extremely electron dense and completely occluded the lumen of the renal tubules, the tubule cells showing signs of mitochondrial degeneration and necrosis. The 'type 2' deposits (Plate 2B) contained several foci and were associated with necrotic debris in the lumen of renal tubules. Both types of deposit appeared as an amorphous central region surrounded by needle-shaped crystals. These crystals often appeared as a halo in the 'type 2' deposits. The depleted zone occurring in some 'type 2' deposits between the needle-shaped crystals and amorphous central core was produced by the crystallization process and indicated that the crystals were produced during specimen preparation by dissolution and reprecipitation of the calculus, which in vivo is probably entirely amorphous.

The sections were examined in the analytical electron microscope to determine the elemental composition of the calculi. The X-ray spectrum of a 'type 1 ' deposit is shown in Fig. $1 \mathrm{~A}$. Elemental peaks were seen for $P(2 \mathrm{keV})$, lead $(2.4 \mathrm{keV}$ also at $10.5,12.6$ and $14.8 \mathrm{keV})$ arising from the counterstain used for contrast enhancement, $\mathrm{Ca}(3.7$ and $4.0 \mathrm{keV})$ and copper ( 8.0 and $8.9 \mathrm{keV})$ derived from the $\mathrm{Cu}$ specimen-support grid. $\mathrm{Mg}$ was not detected in the deposits. Background counts were taken from adjacent areas of the specimen. When 'type 2' deposits were analysed the same elemental peaks were obtained for the amorphous centre and needle-shaped crystals; however, neither $\mathbf{C a}$ nor $\mathbf{P}$ was detected in the intervening clear area. The value for $\mathrm{Ca}: \mathrm{P}$ of the deposits was calculated after subtraction of background counts and by comparison with a $\mathrm{CaHPO}_{4}$ standard (Fig. 1B). The value thus determined was $1.43 \pm 0 \cdot 12: 1.0(n 6)$; the 'whole number' value for the ratio was $3: 2$, i.e. that for tricalcium phosphate (apatite). We were not able to demonstrate the characteristic electron diffraction pattern for apatite.

The concentrations of $\mathrm{Ca}, \mathrm{Na}$ and $\mathrm{K}$ in the muscle of trout given four of the experimental diets are shown in Table 5. It had not been our intention to analyse skeletal muscle and therefore no samples of tissue were taken from the first batch of fish to be examined (those given diet 2). When tissues were taken the next day from the next group of fish, which were those given diet 4 , the skeletal muscle was obviously more flaccid and different in texture from that of normal trout. Consequently muscle samples were taken for analysis from these fish and from those given diets 1,3 and 5 . Tissue samples were taken on subsequent days; tissue collection took place over a $5 \mathrm{~d}$ period. 

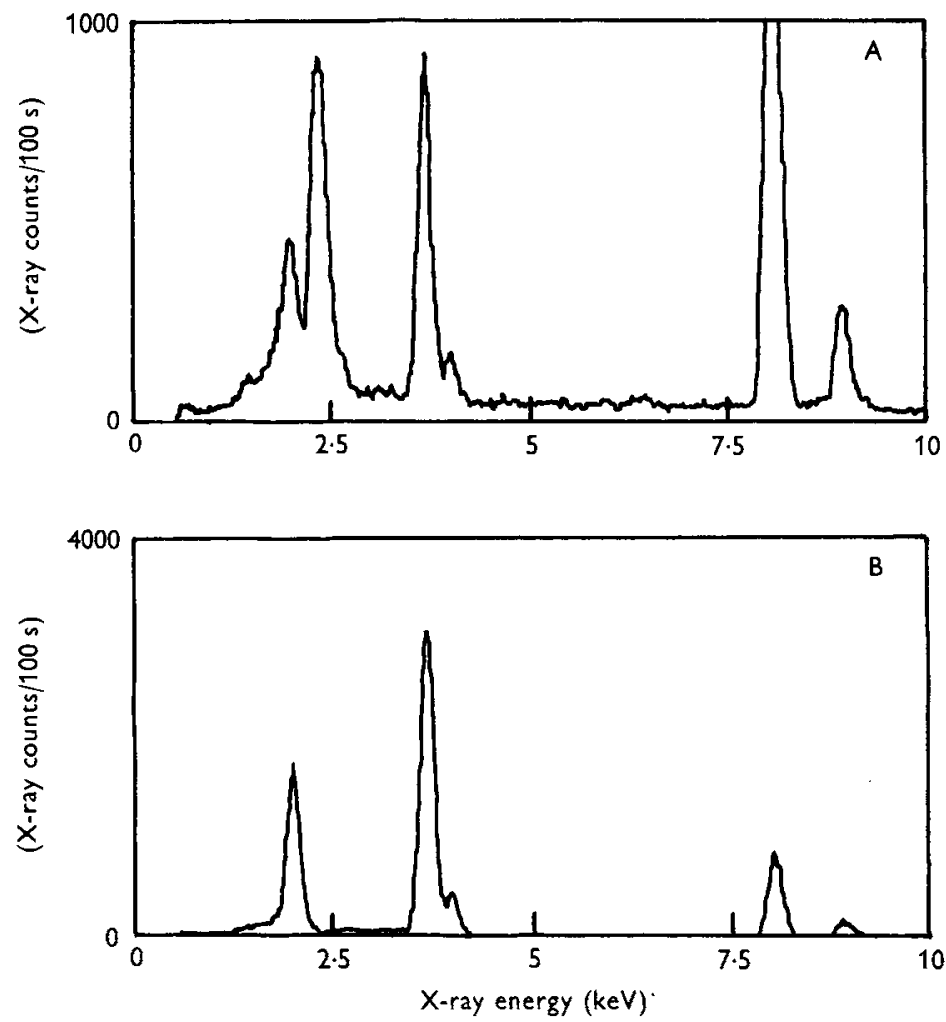

Fig. 1. Analytical electron microscopy of calcified tissue: (A) X-ray spectrum of 'type 1' deposit (see p. 132) in renal tubule of rainbow trout (Salmo gairdneri) given diet 4 (see Table 1); (B) X-ray spectrum of calcium phosphate standard.

Table 5. Mean concentrations ( $m \mathrm{~g} / \mathrm{kg}$ wet weight) of calcium, sodium and potassium in the muscle of rainbow trout (Salmo gairdneri) given diets containing different amounts of calcium, phosphorus and magnesium

(Mean values with their standard errors for ten fish/treatment)

\begin{tabular}{|c|c|c|c|c|c|c|}
\hline \multirow[b]{2}{*}{ Diet no.* } & \multicolumn{2}{|c|}{$\mathrm{Ca}$} & \multicolumn{2}{|c|}{$\mathrm{Na}$} & \multicolumn{2}{|c|}{$\mathbf{K}$} \\
\hline & Mean & SE & Mean & SE & Mean & SE \\
\hline $\begin{array}{l}1 \\
2\end{array}$ & $\begin{array}{c}0.66^{\circ} \\
L\end{array}$ & 0.17 & $\begin{array}{c}827 \mathrm{~s} \\
\mathrm{~L}\end{array}$ & 68 & $\begin{array}{c}5801 \\
\mathrm{~L}\end{array}$ & 282 \\
\hline 3 & $0.41^{\mathrm{b}}$ & 0.05 & $299^{\circ}$ & 17 & $5362^{\mathrm{a}}$ & 88 \\
\hline 4 & $0.96^{\mathrm{B}}$ & 0.17 & $1141^{b}$ & 127 & $4890^{\mathrm{a}}$ & 164 \\
\hline 5 & $0 \cdot 38^{\mathrm{b}}$ & 0.04 & $330^{\circ}$ & 38 & $5019^{\mathrm{a}}$ & 121 \\
\hline
\end{tabular}

Values in the same column with unlike superscripts are significantly different $(P<0.01)$.

L, samples lost.

* For details, see Table 1 .

There were no significant differences in muscle $\mathrm{Mg}$ (mean $\pm \mathrm{SE} 0.25 \pm 0.008 \mathrm{~g} / \mathrm{kg}$ ) or $\mathrm{P}$ (mean \pm SE $2.47 \pm 0.08 \mathrm{~g} / \mathrm{kg}$ ) in the four treatments for which results were available. Levels of both $\mathrm{Na}$ and $\mathrm{Ca}$ in muscle were significantly increased in those trout given diets lacking supplementary $\mathrm{Mg}$. $\mathrm{K}$ concentration in the muscle was not significantly changed by alterations in either the $\mathrm{Ca}$ (diet $3 v$. diet 5 ) or $\mathrm{Mg}$ (diet $4 v$. diet 5) levels in the diet. 
As $\mathrm{K}$ is primarily an intracellular ion and $\mathrm{Na}$ the principal cation in extracellular fluids the observed changes in trout muscle under conditions of $\mathrm{Mg}$ deficiency may be indicative of an increase in extracellular fluid, the tissues becoming oedematous.

\section{DISCUSSION}

Although the tissue abnormalities that occur in trout as a result of $\mathrm{Mg}$ deficiency bear a marked qualitative similarity to those occurring in mammals some differences are apparent at a gross level. Thus there was no mortality in trout given diets containing as little as $26 \mathrm{mg}$ $\mathrm{Mg} / \mathrm{kg}$ and these fish doubled their live weight during a 16-week experimental period. By contrast Britton \& Stokstad (1970) found it necessary to supplement diets containing $80 \mathrm{mg} \mathrm{Mg} / \mathrm{kg}$ with an additional $20 \mathrm{mg} \mathrm{Mg} / \mathrm{kg}$ in order to ensure survival of rats during a $28 \mathrm{~d}$ experimental period. This ability of fish to survive and grow at much lower dietary $\mathrm{Mg}$ levels than the rat may depend on uptake of $\mathrm{Mg}$ from the water. Ogino \& Chiou (1976) include high mortality as a symptom of $\mathrm{Mg}$ deficiency in carp and indeed mortalities of up to $16 \%$ occurred in carp given a diet containing $52 \mathrm{mg} \mathrm{Mg} / \mathrm{kg}$. However, in a second experiment no mortality occurred at dietary $\mathrm{Mg}$ concentrations of $80 \mathrm{mg} / \mathrm{kg}$ even though the requirement of young carp for $\mathrm{Mg}$ was estimated to be $400-500 \mathrm{mg} / \mathrm{kg}$.

The severity of nephrocalcinosis in $\mathrm{Mg}$-deficient rats appears to depend on many factors, including the age of the animal, the duration of the experiment and the basal level of $\mathrm{Mg}$ in the deficient diet. Thus renal $\mathrm{Ca}$ levels may be increased by as little as 4-fold (Macintrye \& Davidsson, 1958) or by more than 100-fold (Britton \& Stokstad, 1970). The Mg concentration in the basal, Mg-deficient diet used by Britton \& Stokstad (1970) was similar to that used in the present work on trout and their findings thus form an appropriate basis for comparison of nephrocalcaemia in the two animals. In their experiments renal Ca levels were as high as $8.3 \mathrm{~g} / \mathrm{kg}$ after rats had been given a Mg-deficient diet $(0.1 \mathrm{mg} \mathrm{Mg} / \mathrm{kg}$ in total) for 4 weeks; this increased renal $\mathrm{Ca}$ level occurred when dietary $\mathrm{Ca}$ levels were quite low $(6.2 \mathrm{~g} / \mathrm{kg})$. The increase in renal Ca concentration in Mg-deficient trout, on the other hand, was much less severe even at a dietary $\mathrm{Ca}$ level of $14 \mathrm{~g} / \mathrm{kg}$ in an experiment of 16 weeks' duration. Possible reasons for the abnormalities being less severe in trout are the availability of some $\mathrm{Mg}$ in the water, and the fact that the freshwater fish normally excretes large amounts of a very hypotonic urine which may assist in removal of $\mathrm{Ca}$ from the kidney.

The low renal $\mathrm{Ca}$ concentrations $(0.17 \mathrm{~g} / \mathrm{kg})$ in the hatchery-reared trout suggest that very high dietary $\mathrm{Ca}$ levels $(50 \mathrm{~g} / \mathrm{kg}$ ) are not deleterious provided a proportionately high dietary level of $\mathrm{Mg}$ is also supplied (the $\mathrm{Mg}$ level in the 'hatchery' diet was $3 \cdot 27 \mathrm{~g} / \mathrm{kg}$ ). In this context it is noteworthy that increasing Ca levels in the experimental diets from approximately $26 \mathrm{~g} / \mathrm{kg}$ (diet 2) to approximately $40 \mathrm{~g} / \mathrm{kg}$ (diet 4) in the absence of supplementary $\mathrm{Mg}$ did not result in any further increase in renal $\mathrm{Ca}$ concentration (Table 4), although the incidence of renal calculi in trout given diet 4 appeared qualitatively greater than in trout given diet 2 .

The marked decrease in serum $\mathrm{Mg}$ concentration in the $\mathrm{Mg}$-deficient trout, while muscle and kidney $\mathrm{Mg}$ levels remained unchanged, is in line with observed effects of $\mathrm{Mg}$ deficiency in the soft tissues of the rat (Britton \& Stokstad, 1970; Elin, Armstrong \& Singer, 1971). $\mathrm{Mg}$ is probably held in a non-diffusable state in the soft tissues, bone $\mathrm{Mg}$ (mainly vertebral column in fish) serving as a reservoir on which soft tissues draw under conditions of $\mathrm{Mg}$ deficiency. Thus, in contrast with the constancy of soft tissue $\mathrm{Mg}$ concentration in $\mathrm{Mg}$ deficient trout, Ogino \& Chiou (1976) observed that the $\mathrm{Mg}$ content of vertebrae of carp decreased from 2.61 to $1.56 \mathrm{~g} / \mathrm{kg}$ dry matter in $\mathrm{Mg}$ deficiency. The skeletal reserve of $\mathrm{Mg}$ in fish is likely to be much less than that of mammals both because fish lack the skeletal structure of mammals and because the vertebrae of fish contain much less $\mathrm{Mg}$ than do typical 

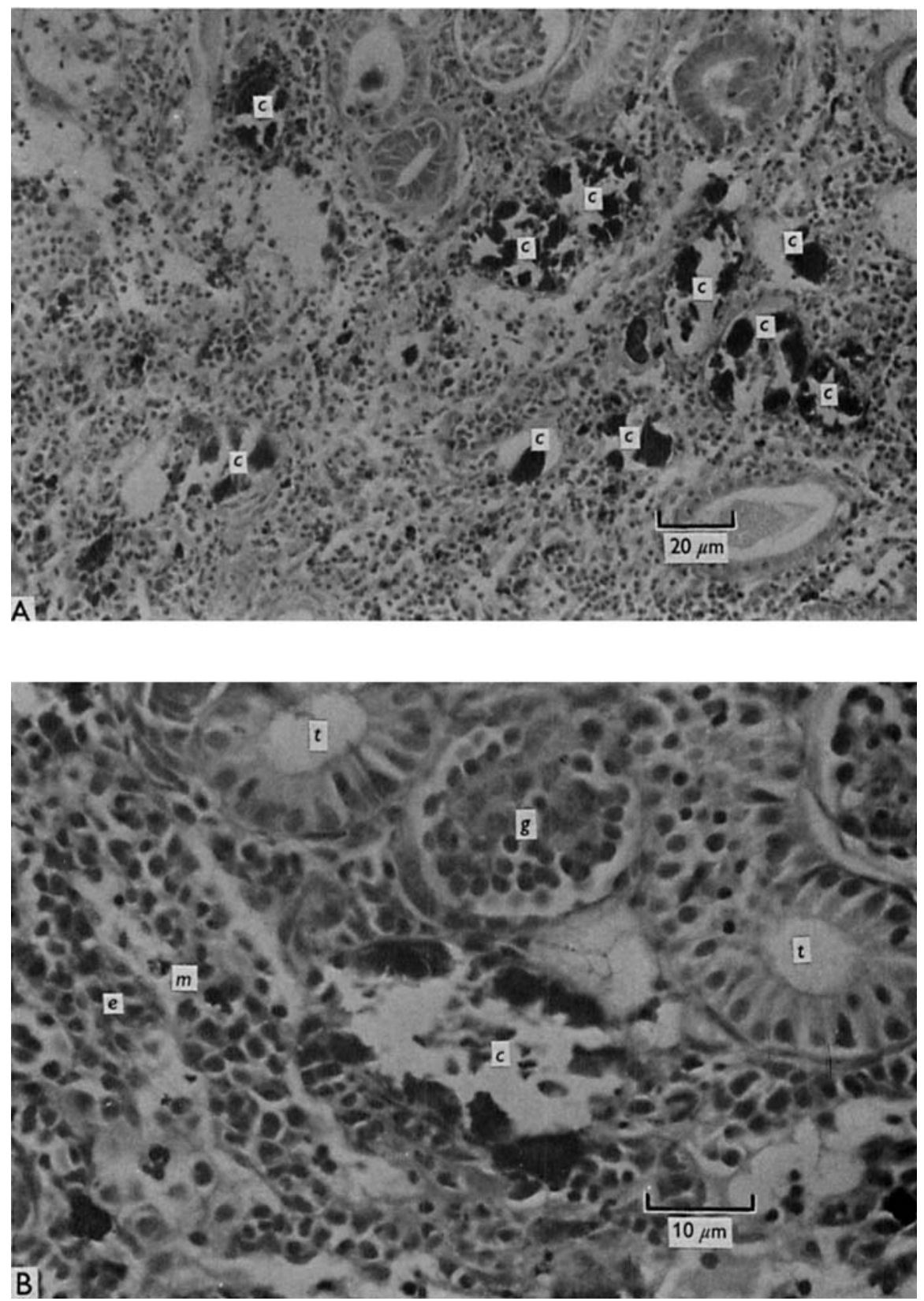

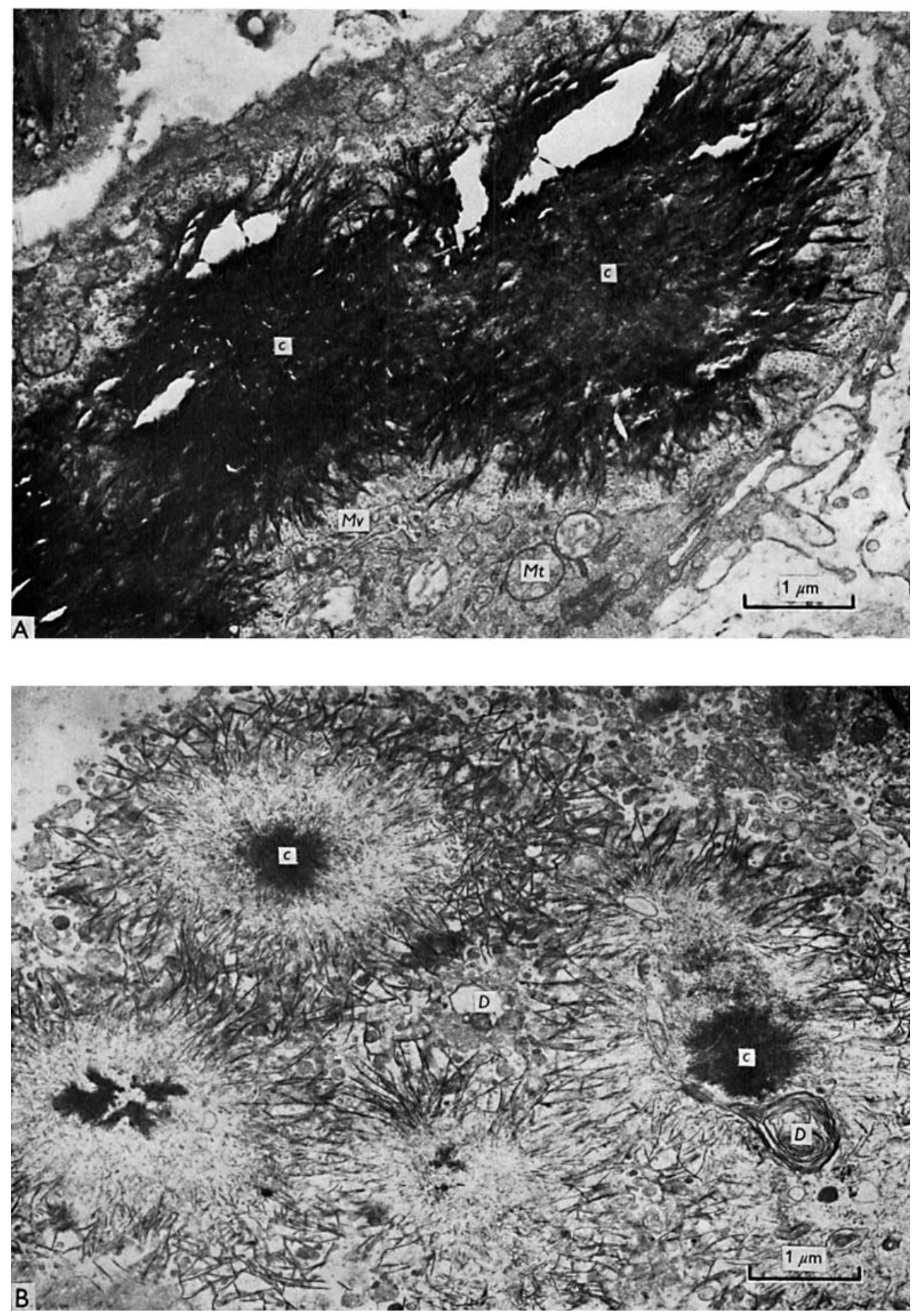

C. B. COWEY AND OTHERS 
bones of mammals (e.g. rat femur $7.3 \mathrm{~g} \mathrm{Mg} / \mathrm{kg}$ bone ash (Elin et al. 1971), carp vertebrae $2.6 \mathrm{~g} \mathrm{Mg} / \mathrm{kg}$ ash (Ogino \& Chiou, 1976)). Many metal-activated enzymes specifically require $\mathrm{Mg}$ as a co-factor and the constancy of $\mathrm{Mg}$ concentration in soft tissues would tend to limit metabolic derangement.

The muscles of $\mathrm{Mg}$-deficient rats have increased concentrations of $\mathrm{Na}$ and reduced concentrations of $\mathrm{K}$; there is a shift in tissue water, the interstitial fluid increasing in quantity and the intracellular fluid decreasing (Elin et al. 1971); the intracellular K concentration also decreases. The increase of $\mathrm{Na}$ concentration in muscle of $\mathrm{Mg}$-deficient trout is indicative of an increase in interstitial fluid. This implies a relative reduction in cellular volume within the muscle tissue as a whole and should lead to a decrease in over-all $\mathrm{K}$ concentration of the muscle. The $\mathrm{K}$ concentration of the muscle did not, however, change significantly in the treatments used. An explanation of this question might be that the intracellular $\mathrm{K}$ concentration actually increases during $\mathrm{Mg}$-deficiency or that $\mathrm{K}$ leaks into the interstitial fluid. These questions are being pursued by attempting to obtain values for volumes of fluid spaces in the muscle under different conditions and on the concentrations of ions in these fluids.

We are indebted to the development laboratories of AEI Scientific Apparatus Ltd, Manchester for provision of the analytical microscope facilities. We thank Dr P. T. Grant for his interest in this work.

\section{REFERENCES}

Bartlett, G. R. (1958). J. biol. Chem. 234, 406.

Britton, W. M. \& Stokstad, E. L. R. (1970). J. Nutr. 100, 1501.

Bunce, G. E., Reeves, P. G., Oba, T. S. \& Sauberlich, H. E. (1963). J. Nutr. 79, 220.

Cowey, C. B., Adron, J. W., Brown, D. A. \& Shanks, A. M. (1975). Br. J. Nutr. 33, 219.

Elin, R. J., Armstrong, W. D. \& Singer, L. (1971). Am. J. Physiol. 220, 543.

Forbes, R. M. (1963). J. Nutr. 80, 321.

Hegsted, D. M., Vitale, J. J. \& McGrath, H. (1956). J. Nutr. 58, 175.

Hickman, C. P. \& Trump, B. F. (1969). In Fish Physiology, vol. 1, p. 91 [W. S. Hoar and D. J. Randall, editors]. New York and London: Academic Press.

Ichikawa, R. \& Oguri, M. (1961). Bull. Jap. Soc. scient. Fish. 27, 351.

Kloppel, T. M. \& Post, G. (1975). J. Nutr, 105, 861.

MacIntyre, I. \& Davidsson, D. (1958). Biochem. J. 70, 456.

O'Dell, B. L., Morris, E. R. \& Regan, W. O. (1960). J. Nutr. 70, 103.

Ogino, C. \& Chiou, J. Y. (1976). Bull. Jap. Soc. scient. Fish. 42, 71.

Pearse, A. G. E. (1972). Histochemistry, Theoretical and Applied, p. 1404. Edinburgh and London: Churchill Livingstone.

Smith, C. E., Brin, M. \& Halver, J. E. (1974). J. Fish Res. Bd Can. 31, 1893.

Templeton, W. L., \& Brown, V. M. (1963). Nature, Lond. 198, 198.

\section{EXPLANATION OF PLATES}

Plate 1 (A). Photomicrograph of kidney from rainbow trout (Salmo gairdneri) given diet 4 (see Table 1) showing the incidence of calcified tubules (c) (stain: phthalocyanin); (B) photomicrograph of kidney from trout given diet 4 showing calcified tubule $(c)$, the calcified area having shattered during sectioning, with necrotic epithelial cells. Normal tubules $(t)$, glomerulus $(g)$, erythropoietic tissue $(e)$ interspersed with melanocytes $(m)$ were also present.

Plate 2 (A). Electron micrograph of calcified kidney tubule from rainbow trout (Salmo gairdneri) given diet 4 (see Table 1). Transverse section of tubule showing lumen occluded by 'type 1 ' deposit (see p. 132) (c). The microvilli $(M v)$ and mitochondria $(M t)$ of the tubular cell appeared intact; (B) electron micrograph of calcified kidney tubule from fish given diet 4 . Section of collecting duct showng 'type 2' deposits (see p. 132) (c) associated with necrotic debris $(D)$. 